\title{
Porcine follicular fluid concentration of free insulin-like growth factor-I collected from different diameter ovarian follicles ${ }^{1}$
}

\author{
Guilherme Oberlender ${ }^{2 *}$, Luis D.S. Murgas ${ }^{3}$, Márcio G. Zangeronimo ${ }^{3}$, Thais P. \\ Pontelo $^{3}$, Tila A. Menezes ${ }^{3}$ and Adriana C. Silva ${ }^{3}$
}

\begin{abstract}
Oberlender G., Murgas L.D.S., Zangeronimo M.G., Pontelo T.P., Menezes T.A. \& Silva A.C. 2013. Porcine follicular fluid concentration of free insulin-like growth factor-I collected from different diameter ovarian follicles. Pesquisa Veterinária Brasileira 33(10):1269-1274. Setor de Fisiologia e Farmacologia Veterinárias, Departamento de Medicina Veterinária, Universidade Federal de Lavras, Campus Universitário s/n, Cx. Postal 3037, Lavras, MG 37200-000, Brazil. E-mail: guilherme.oberlender@uffs.edu.br

The study aimed to quantify the concentrations of free IGF-I in serum and fluid of ovarian follicles in pre-pubertal gilts and describe the ovarian morphology by measuring the size of the ovaries and counting the number of surface follicles. Ovaries $(n=1,000)$ from pre-pubertal gilts were obtained immediately after slaughter. A total of 10 samplings were performed, with ovaries obtained from 50 females for each collection. The follicles situated on the surface of each ovary were classified as small (SFs, 2 to $5 \mathrm{~mm}$ in diameter) or large (LFs 6 to $10 \mathrm{~mm}$ in diameter) and the follicular fluid was obtained by follicle aspiration. The collection of serum samples was performed after the gilts exsanguination using sterile tubes. From the pool of serum and follicular fluid obtained from 50 females, the concentration of free IGF-I was determined in each sample using an enzyme immunoassay kit (ELISA). The description of ovarian morphometry was performed in 100 ovaries from randomly selected gilts. The larger and smaller lengths of ovaries were measured, and the total number of SFs and LFs present on the surface of each ovary were also counted. The IGF-I concentration was greater $(\mathrm{P}<0.05)$ in LFs $(170.92 \pm 88.29 \mathrm{ng} / \mathrm{mL})$ compared with SFs $(67.39 \pm 49.90 \mathrm{ng} /$ $\mathrm{mL})$ and serum $(73.48 \pm 34.63 \mathrm{ng} / \mathrm{mL})$. The largest and smallest length of the ovaries was $26.0 \pm 3.0$ and $19.0 \mathrm{~mm} \pm 2.0 \mathrm{~mm}$, respectively. The number of SFs $(70.86 \pm 25.76)$ was greater $(\mathrm{P}<0.01)$ than LFs $(6.54 \pm 5.26)$. The study concluded that LFs present greater levels of IGF-I when compared with SFs and blood, which is related to increased activity of the LFs and its differentiation to ovulation. In addition, ovaries of pre-pubertal gilts have a higher number of SFs compared to LFs. Therefore, our study demonstrated unique data regarding the physiological concentration of free IGF-I in ovarian follicles, that can be used in future research to evaluate the addition of this hormone in the in vitro production media of porcine embryos with the goal to improve the technique efficiency.
\end{abstract}

INDEX TERMS: Follicular development, IGF-I, ovarian morphometry, reproduction, swine.

RESUMO.- [Concentração do fator de crescimento semelhante à insulina tipo I no fluido folicular suíno coletado a partir de folículos ovarianos de diferentes

\footnotetext{
${ }^{1}$ Received on January 8, 2013.

Accepted for publication on September 11, 2013

${ }^{2}$ Curso de Medicina Veterinária, Universidade Federal da Fronteira Sul (UFFS), Campus Realiza s/n, Cx. Postal 253, Realeza, PR 85770-000, Brasil.*Corresponding author: guilherme.oberlender@uffs.edu.br

${ }^{3}$ Setor de Fisiologia e Farmacologia Veterinárias, Departamento de Medicina Veterinária, Universidade Federal de Lavras, Campus Universitário s/n, Cx. Postal 3037, Lavras, MG 37200-000, Brazil.
}

diâmetros.] Objetivou-se quantificar as concentrações do IGF-I livre no soro e no fluido de folículos ovarianos de fêmeas suínas pré-púberes e descrever a morfologia ovariana, por meio da mensuração das dimensões dos ovários e da contagem do número de folículos superficiais. Ovários ( $\mathrm{n}=1.000)$ foram obtidos de fêmeas pré-púberes imediatamente após o abate. Foi realizado um total de 10 coletas, sendo em cada, obtidos ovários de 50 fêmeas. Os folículos localizados na superfície de cada ovário foram classificados em pequenos (FPs, 2-5mm de diâmetro) ou grandes (FGs, 
6-10mm de diâmetro) e o fluido folicular foi obtido por aspiração dos folículos. A coleta do soro foi realizada após a exsanguinação das fêmeas com o uso de tubos estéreis. A partir do pool de fluido folicular e do soro obtido das 50 fêmeas, determinou-se a concentração de IGF-I livre em cada amostra por meio de kit de ensaio imunoenzimático (ELISA). A descrição da morfometria ovariana foi realizada em 100 ovários provenientes de fêmeas escolhidas aleatoriamente. Foi mensurado o comprimento maior e menor dos ovários e, também, contabilizado o número total de FPs e FGs presentes na superfície de cada ovário. A concentração de IGF-I foi superior $(\mathrm{P}<0,05)$ nos $F G s \quad(170,92 \pm 88,29$ ng/ $\mathrm{mL})$ em comparação com os FPs $(67,39 \pm 49,90 \mathrm{ng} / \mathrm{mL})$ e o sérico $(73,48 \pm 34,63 \mathrm{ng} / \mathrm{mL})$. 0 comprimento maior e menor dos ovários foi de $26,0 \pm 3,0 \mathrm{~mm}$ e $19,0 \pm 2,0 \mathrm{~mm}$, respectivamente. 0 número de FPs $(70,86 \pm 25,76)$ foi maior $(\mathrm{P}<0,01)$ em comparação com os FGs $(6,54 \pm 5,26)$. Conclui-se que FGs apresentam níveis de IGF-I superiores aos FPs, e ao sangue, sendo isso relacionado a maior atividade dos FGs e à diferenciação que os mesmos sofrem para a ovulação. Além disso, ovários de fêmeas suínas pré-púberes apresentam elevado número de FPs em comparação aos FGs. Portanto, nosso estudo demonstrou dados originais a respeito da concentração fisiológica de IGF-I livre em folículos ovarianos, que podem ser utilizados em futuras pesquisas para avaliar a adição desse hormônio nos meios de produção in vitro de embriões suínos com o objetivo de melhorar a eficiência da técnica.

TERMOS DE INDEXAÇÃO: Desenvolvimento folicular, IGF-I, morfometria ovariana, reprodução, suíno.

\section{INTRODUCTION}

The development of ovarian follicles during the oestrous cycle in mammals involves a coordinated process of replication and cell differentiation. This process increases the number of granulosa cells which lining the oocyte, the antral follicle formation and expansion and also the formation of the follicular fluid (FF) (Clarke et al. 2006). Furthermore, the follicular growth is extremely important, because only large follicles (greater than $6 \mathrm{~mm}$ in diameter, in pigs) can ovulate (Trout et al. 1992, Kanitz et al. 2001, Knox 2005).

In this context, the role of growth factors in follicular development, including IGF-I (Samaras et al. 1994, Monget et al. 2002), has been extensively studied, as it is known that this hormone acts to promote both the growth and differentiation of granulosa cells, the development of pre-antral and antral follicle formation (Mao et al. 2004).

The first study to report the presence of IGF-I in the ovaries of sows was described by Hammond et al. (1985), who isolated surface follicles and quantified the IGF-I concentration present in FF. Further studies have demonstrated the involvement of this growth factor in numerous ovarian functions such as, for example, the increase of steroidogenesis induced by FSH and the increase of progesterone and androgen production (Spicer \& Echternkamp 1995). These effects are mediated by IGF-I binding to specific receptors present in the granulosa cells (Pawshe, Rao \& Totey 1998).

Approximately $80 \%$ of circulating IGF-I is derived from the liver, where the production is stimulated by growth hormone (GH), which is its main regulator (Frystyk 2004, Higashi et al. 2012). However, according to Daftary \& Gore (2005), IGF-I can also be produced by other tissues, for example in granulosa cells of ovarian follicles (Hammond et al. 1985).

Studies in bovines and equines have shown that concentrations of free IGF-I (biologically active) in the FF increase during follicular growth and selection and are higher in LFs (pre-ovulatory) compared to subordinate follicles (Santiago et al. 2005, Spicer et al. 2005). On the other hand, few studies have examined the physiological concentration of free IGF-I present in the FF of gilts. Hammond et al. (1985) and Howard \& Ford (1992) evaluated the IGF-I concentration in FF by measuring total (free and protein-bound) levels of the hormone. According to Frystyk (2004), the evaluation of total concentration as an estimate of IGF-I is widely used due to the lack of free IGF-I assays available. However, the IGF binding proteins (IGFBPs) can change the IGF-I bioactivity without altering the measurable concentrations of the hormone. Therefore, IGF-I concentration may be better correlated with their free fractions than with the total levels.

Keeping in mind the functions of IGF-I in female reproduction, its ovarian effects and its presence in FF, studies have been conducted using its addition to the in vitro production (IVP) media of pig embryos (Reed et al. 1993, Xia, Tekpetey \& Armstrong 1994, Grupen, Nagashima \& Nottle 1997, Illera et al. 1998, Cui et al. 2005, Kim et al. 2005). However, despite the development of in vitro maturation (IVM), in vitro fertilisation (IVF) and in vitro culture (IVC) techniques for embryos, they still have several limitations, such as high rates of polyspermy (Coy \& Romar 2002). Therefore, the best protocol to be used at various stages of embryo IVP technique is not yet established, as the addition of hormones and other substances are possible alternatives for the improvement of techniques in order to obtain better results.

In IVM, the addition of FF obtained from large follicles (over $5 \mathrm{~mm}$ ) is usually used (Vatzias \& Hagen 1999, Algriany et al. 2004). However, the ovaries of pre-pubertal gilts, which are often used in IVM (Coy \& Romar 2002), carry a high number of small follicles (less than $5 \mathrm{~mm}$ in diameter) (Bagg et al. 2004, Knox 2005). Thus, obtaining the $\mathrm{FF}$ of LFs (above $5 \mathrm{~mm}$ in diameter) is limited by the small number of these follicles in the ovary. Therefore, studies aimed at evaluating new techniques that enable the use of FF obtained from small follicles, either in the presence or absence of other substances/factors in IVM, are needed in an attempt to maximise the technique, and could represent a major advance in IVP of porcine embryos.

The initial step prior to assessing the effects of the addition of hormones, including IGF-I, to the means of IVP of embryos with the use of FF, is to determine the physiological concentrations present in ovarian follicles, thereby better meeting the conditions for performing IVF with the addition of this hormone. Considering the above, this study aimed to evaluate the physiological concentration of free IGF-I present in pre-pubertal gilts' FF, collected from antral follicles of different sizes. Moreover, the study aimed to de- 
termine the size of ovaries and the total number of follicles of two different diameter classes on their surfaces.

\section{MATERIALS AND METHODS}

\section{Ethics}

The present study was conducted after the institutional approval of the Federal University of Lavras (UFLA), with all experimental protocols being compliant with the Ethical Principles of Animal Experiments adopted by the Institutional Animal Care and Use Committee Guidelines of this institution, under the protocol number 009/10.

\section{Place of investigation and location of animals}

The study was performed in the laboratory of in vitro fertilisation and embryo culture in pigs, located in the Department of Veterinary Medicine at UFLA. All biological material was obtained from a slaughterhouse ("Matadouro/Frigorífico NUTRILI") situated in Lavras city, Minas Gerais state, Brazil, during the months of May to October 2012. A total of 500 Landrace $\times$ Large White pre-pubertal gilts (lineage cross-bred commercial - Genetics AGROCERES) aged 5 to 6 months and weighing between 90 to $100 \mathrm{~kg}$ on average were used.

\section{Media}

Phosphate-Buffered Saline (PBS) was purchased from Dako North America, Inc. (California, United States). The IGF-I assay kit was obtained from USCN Life Science, Inc. (California, United States). Unless otherwise indicated, all the chemicals and reagents used in this study were purchased from Sigma-Aldrich Brasil Ltda. (São Paulo, Brazil). All of the media employed were prepared using ultrapure water - Milli-Q, $18.2 \mathrm{M} \Omega \mathrm{cm}^{-1}$ (Direct-Q 5, Millipore, Darmstadt, Germany).

\section{Ovary collection}

Ovaries isolated $(n=1,000)$ from 500 pre-pubertal gilts were collected immediately after slaughter. Following collection, the ovaries were transported to the laboratory within a period not exceeding one hour in $0.9 \%$ (w:v) $\mathrm{NaCl}$ solution containing $0.1 \%$ kanamycin sulphate at $38^{\circ} \mathrm{C}$. Following this, the ovaries were washed twice in $0.04 \%(\mathrm{v}: \mathrm{v})$ cetrimide (hexadecyltrimethylammonium bromide) solution and twice in saline, both at $38^{\circ} \mathrm{C}$. After, the process for obtaining the ovarian follicles FF was carried out.

\section{Follicular fluid collection and preparation}

The time elapsed from animal slaughter to follicular fluid recovery did not exceed 4 hours. Using an 18-gauge needle and a disposable $10-\mathrm{mL}$ syringe, the FF was aspirated from antral follicles on the surface of each collected ovary and divided into two categories: small follicles (SFs, 2 to $5 \mathrm{~mm}$ in diameter) and large follicles (LFs, 6 to $10 \mathrm{~mm}$ in diameter) (Knox 2005, Ito et al. 2008, Oberlender et al. 2013). The follicles measurement in both categories was performed with the aid of stereoscopic microscope (Q740SZ-TR Quimis, Diadema, São Paulo, SP, Brazil) with millimetered eyepiece and using a ruler graduated in millimetres. Once aspirated, the pool of FF obtained in each category (SFFs, FF of small follicles and LFFs, FF of large follicles) was centrifuged at $1,500 \times \mathrm{g}$ for $30 \mathrm{~min}$ at $24^{\circ} \mathrm{C}$ in order to remove follicular and ovary cells and debris (Park et al. 2009). Then, the supernatants obtained were collected and filtered through a $0.22 \mu \mathrm{m}$ membrane filter (Millex-GP, Merck Millipore, Massachusetts, United States), aliquoted into $1-\mathrm{mL}$ microtubes and immediately stored at $-20^{\circ} \mathrm{C}$ until the analyses were performed (Asano \& Niwa 2004). During the process of follicle aspiration, the ovaries remained in a glass beaker $(1,000 \mathrm{~mL})$ immersed in saline solution with $0.1 \%$ kanamycin sulphate added under a heat plate at $37^{\circ} \mathrm{C}$.

\section{Ovary morphometry evaluation}

The ovarian morphometry was evaluated from the gilts' ovaries by measuring the largest and smallest length using a ruler graduated in millimetres. The counting of antral SFs and LFs present just on the ovarian surface (approximately 25\% of the ovarian follicles population) was performed according Rhind \& Schanbacher (1991) using four wire loops with inside diameters of 2, 5, 6 and $10 \mathrm{~mm}$. Subsequently, the content (FF) of the measured follicle was aspirated, and then, the remaining follicles were measured in the same manner.

\section{Blood collection}

After the electric stunning of the gilts, blood samples were collected during exsanguination using $10-\mathrm{mL}$ sterile tubes containing a clot activator gel (Labor Import, Shandong Weichai Huafeng Power Co Ltd - RPC, Weifang Shandong, Shandong, China). Then, the samples obtained were immediately kept in an isothermal container with ice and after transported to the laboratory. Blood samples were stored for 1 hour at room temperature $\left(24^{\circ} \mathrm{C}\right)$ and then centrifuged at $1,000 \times \mathrm{g}$ for $20 \mathrm{~min}$ at $4^{\circ} \mathrm{C}$ in a refrigerated centrifuge (Megafuge $16 R$, Thermo Scientific, Bremen, Germany). Immediately after the centrifugation, the equivalent of $1.5 \mathrm{~mL}$ of serum was collected from each sample and added together in a $250 \mathrm{~mL}$ beaker (Chatterjee et al. 2001). Afterwards, from the serum pool obtained $1.0 \mathrm{~mL}$ aliquots were prepared in microtubes and stored in an ultra-freezer at a temperature of $-80^{\circ} \mathrm{C}$ until the analyses were performed.

\section{IGF-I free assay}

For the hormone analysis, the serum and FF samples were thawed and diluted $(1: 1,000)$ in phosphate saline buffer (PBS, $\mathrm{pH} 7.0$, $0.02 \mathrm{~mol} / \mathrm{L}$ ). Concentrations of free IGF-I in serum and FF were determined in triplicate $100-\mu \mathrm{L}$ aliquots by enzyme immunoassay - ELISA (E90050Po ELISA kit $1 \times 96$ well) specific to the pig insulin-like growth factor type I (IGF-I). The assay was carried out according to the protocol established by the manufacturer. Briefly, the microtiter plate was pre-coated with antibody specific for pig IGF-I. Subsequently, the standards and samples were added to microtiter plate with a specific antibody preparation. Then, the other antibody was added. After, the substrate solution was added and only those wells that contained IGF-I exhibited a colour change. Thereafter, the enzyme-substrate reaction was terminated by sulfuric acid solution addition and the change in colour was measured using a spectrophotometer. The minimum sensitivity was $0.0066 \mathrm{ng} / \mathrm{mL}$ and, intra- and inter-assay variation coefficients (CV) were $<10 \%$ and $<12 \%$, respectively. The resulting optical density of samples reading were obtained from a microplate reader (Multiskan FC, Thermo Scientific, Bremen, Germany) and the IGF-I concentrations calculated from a standard curve on log-log.

\section{Experimental design}

For the acquisition of the 500 gilts $(1,000$ ovaries) ten repetitions were performed (days of collection), and in each, ovaries and blood serum samples of 50 females were collected and handled as described previously. Thus, for each day of collection, blood samples and SFFs and LFFs were obtained.

For the ovarian morphometry assessment (larger and smaller lengths) and the number of follicles on the ovarian surface, a total of 100 ovaries were used from 50 gilts, from which five females were obtained for each of the 10 days of collection.

To assess the concentration of free IGF-I present in the SFFs, LFFs and blood, a randomised block design with three treatments (SFFs, LFFs and blood) was used. The blocks consisted of the col- 
lection days. A total of 10 repetitions were performed and each experimental plot was represented by 50 gilts.

\section{Statistical analysis}

Data are presented as mean \pm standard deviation. A normality test was performed (Kolmogorov-Smirnov) and, subsequently, the data were submitted to non-parametric analysis, since they did not reach normality. To evaluate the ovarian follicle number, the means of the treatments (SFs and LFs) were compared by the Mann-Whitney test. To assess the levels of free IGF-I between the SFFs, LFFs and serum, the treatment means were compared by Mann-Whitney test when they were significant using the Kruskal-Wallis test. A significance level of $5 \%$ was considered to indicate a statistical difference. All statistical analyses were performed using the statistical package SPSS for Windows version $17.0^{4}$.

\section{RESULTS}

In the assessment of ovarian morphometry, the highest and lowest average length of the ovaries was 26.0 \pm 3.0 and

${ }^{4}$ SPSS Statistics 17.0, Rel. 17.0.1. 2008, SPSS Inc., Chicago, IL.

Table 1. Number (mean \pm SD) of small (SFs) and large follicles (LFs) found on the ovarian surface from pre-pubertal gilts $(n=100$ ovaries)

\begin{tabular}{lccc}
\hline Treatment* & $\begin{array}{c}\text { Number of } \\
\text { follicles* }\end{array}$ & $\begin{array}{c}\text { Maximum } \\
\text { value }\end{array}$ & $\begin{array}{c}\text { Minimum } \\
\text { value }\end{array}$ \\
\hline Small follicles (SFs) & $\begin{array}{c}70.86 \pm 25.76 \mathrm{a} \\
\text { Large follicles (LFs) }\end{array}$ & 13 & 154 \\
General mean & $38.70 \pm 37.19$ & 0 & 26 \\
$\quad \mathrm{P}<0.01$ & & \\
a,b & Means followed by different letters in the column differ by Mann-Whi- \\
tney test $(\mathrm{P}<0.01)$. & SFs $=2$ to $5 \mathrm{~mm}$ in diameter and LFs $=6$ to $10 \mathrm{~mm}$ \\
in diameter. &
\end{tabular}

Table 2. Ovarian and blood levels of free IGF-I $(\mathrm{ng} / \mathrm{mL})$ in pre-pubertal gilts $(n=500)$

\begin{tabular}{lcccc}
\hline Analysed & \multicolumn{2}{c}{ Follicular Fluid* } & Blood & $\begin{array}{c}\text { P } \\
\text { variable }\end{array}$ \\
\cline { 2 - 3 } value \\
\hline IGF-I & $\begin{array}{c}\text { SFs } \\
\text { 67.39 } \pm\end{array}$ & $\begin{array}{c}170.92 \pm \\
\text { LFs }\end{array}$ & $73.48 \pm$ & 0.04 \\
& $49.90 \mathrm{~b}$ & $88.29 \mathrm{a}$ & $34.63 \mathrm{~b}$ &
\end{tabular}

$\overline{a, b}$ Means followed by different letters in the line differ by Mann-Whitney test $(\mathrm{P}<0.05) .{ }^{*} \mathrm{SFs}=$ small follicles $(2$ to $5 \mathrm{~mm}$ in diameter $)$ and $\mathrm{LFs}=$ large follicles (6 to $10 \mathrm{~mm}$ in diameter).

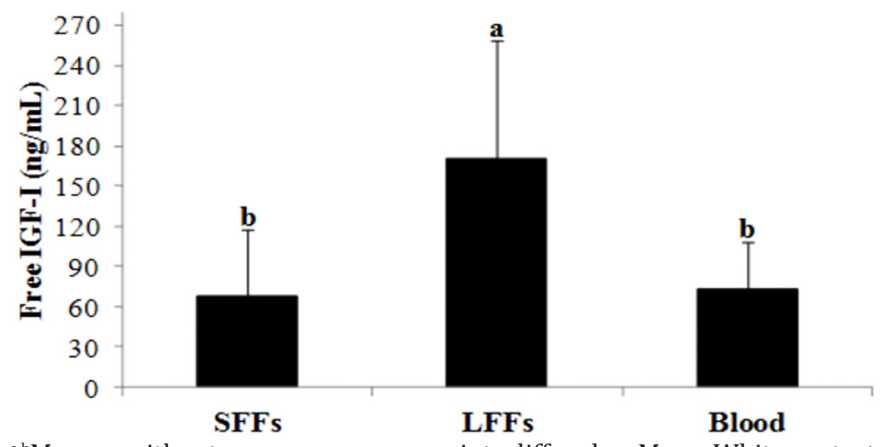

a,b Means without common superscript differ by Mann-Whitney test $(\mathrm{P}=0.04)$.

Fig.1. Concentration of free IGF-I in follicular fluid (FF) collected from small follicles (SFFs, 2 to $5 \mathrm{~mm}$ in diameter), large follicles (LFFs, 6 to $10 \mathrm{~mm}$ in diameter) and blood from pre-pubertal gilts $(n=500)$.
$19.0 \pm 2.0 \mathrm{~mm}$, respectively. It was observed that the number of SFs was greater $(\mathrm{P}<0.01)$ compared with LFs (Table 1$)$.

The free IGF-I concentration was higher $(\mathrm{P}<0.05)$ in the LFFs when compared with SFFs and blood (Table 2, Fig.1). The LFs $(170.92 \pm 88.29 \mathrm{ng} / \mathrm{mL})$ contained 2.6 - and 2.4-fold greater $(\mathrm{P}<0.05)$ levels of free IGF-I than SFs $(67.39 \pm 49.90 \mathrm{ng} / \mathrm{mL})$ and blood $(73.48 \pm 34.63 \mathrm{ng} / \mathrm{mL})$, respectively (Table 2).

\section{DISCUSSION}

This study described the ovarian morphometry (ovarian size and number of follicles) of pre-pubertal gilts and also determined the free IGF-I levels present in the FF of follicles of two different diameters.

The morphology of ovaries obtained showed characteristic of pre-pubertal animals, in the other words, ovaries without the presence of albicans body and corpus luteum or ovulation signals (Bagg et al. 2004, Knox 2005). This finding can be confirmed by the greater number of SFs (smaller than $5 \mathrm{~mm}$ in diameter) on the ovary surface.

The results of ovarian morphometry were similar to those obtained by Bagg et al. (2004), who found an average of $24.1 \mathrm{~mm}$ for the greatest length and $15.9 \mathrm{~mm}$ for the smallest ovary length from pre-pubertal gilts of the same breed used in this study. Regarding the number of follicles on ovarian surface, a larger number of SFs compared with LFs is justified, because in pre-pubertal gilts, the surface follicles smaller than $6 \mathrm{~mm}$ are abundantly present, over the larger follicles and luteal structures (Knox 2005).

The average number of SFs obtained in this study showed similarity to the data described by Knox (2005), who obtained an average of 80 small follicles in the gilts ovaries. The general mean of the ovarian follicles number (follicles between 2 and $10 \mathrm{~mm}$ in diameter) was close to the results obtained by Bagg et al. (2004), which also evaluated the number of surface ovarian follicles in pre-pubertal gilts (46.8).

The concentrations of IGF-I obtained differ from those shown by Hammond et al. (1985) in follicles greater than $6 \mathrm{~mm}$ of diameter, which described a mean level of 104ng/ $\mathrm{mL}$. This finding can be justified by the small number of animals used in their study (nine animals) compared to our study and also by the method of assessing the concentrations of IGF-I, which was by radioimmunoassay.

According to Spicer et al. (2005), the increased concentration of IGF-I levels during the follicular development demonstrates that the levels of this hormone are physiologically regulated by ovarian autocrine and paracrine control. Thus, the changes in IGF-I in FF are due to a change in the local production of IGF-I by granulosa and theca cells.

In general, IGF-I concentrations in the FF are equal or lower as compared to blood (Spicer \& Echternkamp 1995). However, an increase in follicular concentration of free IGFI, or bioavailable, plays a role in follicular differentiation by means of an action on the potentiation of gonadotropins (Spicer et al. 2005). Therefore, a high level of IGF-I on the LFFs compared with blood is expected with follicular development. This fact was demonstrated in our study in which it was observed that the concentration of free IGF-I was similar between the blood and SFFs, but higher in the LFFs. 
In the present study it was shown that concentrations of free IGF-I are greater in LFs than in follicles smaller than $5 \mathrm{~mm}$ in diameter. These findings are in accordance with the data described in cattle (Santiago et al. 2005) and mares (Spicer et al. 2005) during follicular growth.

According to Yoon et al. (2000), the IVP of porcine embryos is impacted by the addition of FF to culture media, with effects dependent on the size of the follicles from which the FF was obtained. Such differences can lead to differential success rates, because there can be differences in the amounts of substances and factors present in follicles of different sizes. Ovaries from prepubertal gilts are routinely used for IVP of embryos (Coy \& Romar 2002). From such ovaries, SFs are more numerous than follicles LFs (Bagg et al. 2004, Knox 2005). Thus, techniques and protocols that improve efficacy when using FF obtained from SFs, with or without the addition of other substances/factors in IVM media, would greatly advance IVP of porcine embryos. Therefore, the determination of physiological levels of free IGF-I in the SFs and LFs of pre-pubertal gilts, as demonstrated in the present study, may be useful in supporting future studies related to the IVP of pig embryos with the addition of this hormone.

$\mathrm{FF}$ is commonly added to porcine IVP of pig embryos media because of its capacity to increase successful maturation rate, promote male pronucleus formation, and increase the rate of monospermic fertilization. The benefits from FF may be augmented by growth factors, amino acids, and hormones, among other substances that promote oocyte maturation and fertilization (Algriany et al. 2004). Thus, considering that the number of SFs is elevated in the ovary of pre-pubertal gilts (Bagg et al. 2004, Knox 2005), and as shown in this study, the use of FF in the IVM and IVF protocols with the addition of IGF-I might be an interesting alternative for improving the efficiency of the technique.

In this context, the addition of IGF-I to the IVP media has been evaluated in many species, such as cattle (Neira et al. 2010), buffalo (Singhal et al. 2009) and caprine (Zhou \& Zhang 2005). In these studies positive effects of IGF-I addition has been demonstrated and the concentration of the hormone used varied from 50 to $100 \mathrm{ng} / \mathrm{mL}$. Likewise, with the goal of improve the efficiency of IVP of porcine embryos, the use of IGF-I to media for both culture and embryo production should be investigated.

Regarding the methodology performed to assess the free IGF-I levels, there is still no consensus. Currently, the predominant tests used to evaluate IGF-I include ultra-filtration by centrifugation and direct immunoassays based on antibodies for no biding IGF-I (Frystyk 2004). The assessment by direct immunoassay presents the same sensitivity when compared with ultra-filtration; however, ultrafiltration has a higher coefficient of variation, because it requires two steps in its analysis: ultra-filtration and the subsequent immunoassay. Thus, both steps contribute to the inaccuracy of the result (Frystyk et al. 2001). On the other hand, the direct immunoassay is technically less demanding and less difficult, besides allowing the determination of IGF-I on a large scale and in a large number of samples.
Despite these advantages, direct immunoassay can provide overestimated results of the concentration of free IGF-I, due to the fact that the antibody will exhaust the free IGF-I (antigen) during the incubation time of the sample and inevitably promote the dissociation of the IGF-I/IGFPB complex (Frystyk 2004). Therefore, the incubation time of the sample to be analysed must follow strictly what the manufacturer stipulated. Moreover, the temperature can also affect the results of the assay. Given this fact, to determine the concentration of IGF-I by means of direct immunoassay, is described that actually obtains the sum of free IGF-I and IGF-I easily separable.

In this study, a specific immunoassay kit was used for determining free IGF-I in serum and any pig biological fluid. Despite the possible changes that samples evaluated in the present study could suffer due to the aspects discussed previously, care was taken to correctly follow the analysis protocol established by the manufacturer; moreover, to reduce bias the analysis was performed in triplicate for each of the samples.

The present study provides new insights into the physiological concentrations of free IGF-I found in ovarian follicles of different sizes, since there is little information in the literature on the physiological values of this free hormone in pre-pubertal gilts. In this context, it was observed that the intrafollicular concentration of free IGF-I increases during follicular development in pigs, a fact that is related to the increased activity of LFs and its differentiation during development to ovulation.

\section{CONCLUSIONS}

The present study allows us to conclude that in LFFs, the free IGF-I concentration is higher (about 2.6-fold greater) compared to its concentration in SFFs.

However, pre-pubertal gilts have a high follicle population that are smaller than $5 \mathrm{~mm}$ in diameter. Thus, studies involving the addition of IGF-I and SFFs to the media of pigs IVF and IVM can be performed from the knowledge of physiological concentrations of this hormone in $\mathrm{FF}$, and then to evaluate the potential of IGF-I and SFFs to increase the efficiency of IVP of pig embryos.

Therefore, our study demonstrated unique data regarding the physiological concentration of free IGF-I in ovarian follicles, that can be used in future research to evaluate the addition of this hormone in the IVP media of porcine embryos with the goal to improve the technique efficiency.

Acknowledgements.- The authors would like to thank Prof. Dr. Antônia dos Reis Figueira (DFP/UFLA) and Mrs. Luciana de Paiva Godinho (DFP/ UFLA) for their generous help with the microplate reader supply for the ELISA assay and the staff of the slaughterhouse "Matadouro/Frigorífico NUTRILI" for supplying the biological samples used in this study. The study was also financially supported by CNPq, CAPES (PNPD Institucional and Pró-equipamentos 2010), FAPEMIG (SHA-APQ-02548-10), Departments of Veterinary Medicine and Animal Science and Post graduate Programs in Animal Science and Veterinary Science of UFLA.

\section{REFERENCES}

Algriany O., Bevers M., Schoevers E., Colenbrander B. \& Dieleman S. 2004. Follicle size-dependent effects of sow follicular fluid on in vitro cumulus 
expansion, nuclear maturation and blastocyst formation of sow cumulus oocytes complexes. Theriogenology 62:1483-1497.

Asano A. \& Niwa K. 2004. Activation and penetration in vitro of pig oocytes treated with calcium ionophore. J. Reprod. Dev. 50:77-85.

Bagg M.A., Vassena R., Papasso-Brambilla E., Grupen C.G., Armstrong D.T. \& Gandolfi F. 2004. Changes in ovarian, follicular, and oocyte morphology immediately after the onset of puberty are not accompanied by an increase in oocyte developmental competence in the pig. Theriogenology 62:1003-1011.

Chatterjee A., Harrison C.J., Britt W.J. \& Bewtra C. 2001. Modification of maternal and congenital cytomegalovirus infection by anti-glycoprotein $\mathrm{b}$ antibody transfer in guinea pigs. J. Infect. Dis. 183:1547-1553.

Clarke H.G., Hope S.A., Byers S. \& Rodgers R.J. 2006. Formation of ovarian follicular fluid may be due to the osmotic potential of large glycosaminoglycans and proteoglycans. Reproduction 132:119-131.

Coy P. \& Romar R. 2002. In vitro production of pig embryos: a point of view. Reprod. Fertil. Dev. 14:275-286.

Coy P., Grullón L., Cánovas S., Romar R., Matás C. \& Avilés M. 2008. Hardening of the zona pellucida of unfertilized eggs can reduce polyspermic fertilization in the pig and cow. Reproduction 135:19-27.

Cui X.S., Jeong Y.J., Jun J.H. \& Kim N.H. 2005. Insulin-like growth factor-I alters apoptosis related genes and reduces apoptosis in porcine parthenotes developing in vitro. Theriogenology 63:1070-1080.

Daftary S.S. \& Gore A.C. 2005. IGF-1 in the brain as a regulator of reproductive neuroendocrine function. Exp. Biol. Med. 230:292-306.

Frystyk J., Ivarsen P., Støving R.K., Dall R., Bek T., Hagen C. \& Ørskov H. 2001. Determination of free insulin-like growth factor-I in human serum: comparison of ultrafiltration and direct immunoradiometric assay. Growth Horm. IGF Res. 11:117-127.

Frystyk J. 2004. Free insulin-like growth factors - measurements and relationships to growth hormone secretion and glucose homeostasis. Growth Horm. IGF Res. 14:337-375.

Grupen C.G., Nagashima H. \& Nottle M.B. 1997. Role of epidermal growth factor and insulin-like growth factor-I on porcine oocyte maturation and embryonic development in vitro. Reprod. Fertil. Dev. 9:571-575.

Hammond J.M., Baranao J.L., Skaleris D., Knight A.B., Romanus J.A. \& Rechler M.M. 1985. Production of insulin-like growth factors by ovarian granulosa cells. Endocrinology 117:2553-2555.

Higashi Y., Sukhanov S., Anwar A., Shai S.Y. \& Delafontaine P. 2012. Aging, atherosclerosis, and IGF-1. J. Gerontol. A, Biol. Sci. Med. Sci. 67:626-639.

Howard H.J. \& Ford J.J. 1992. Relationships among concentrations of steroids, inhibin, insulin-like growth factor-1 (IGF-1), and IGF-binding proteins during follicular development in weaned sows. Biol. Reprod. 47:193-201.

Illera M.J., Lorenzo P.L., Illera J.C. \& Petters R.M. 1998. Developmental competence of immature pig oocytes under the influence of EGF, IGF-I, follicular fluid and gonadotropins during IVM-IVF processes. Int. J. Dev. Biol. 42:1169-1172.

Ito M., Iwata H., Kitagawa M., Kon Y., Kuwayama T. \& Monji Y. 2008. Effect of follicular fluid collected from various diameter follicles on the progression of nuclear maturation and developmental competence of pig oocytes. Anim. Reprod. Sci. 106:421-430.

Kanitz W., Brüssow K.P., Becker F., Torner H., Schneider F., Kubelka M. \& Tomek W. 2001. Comparative aspects of follicular development, follicular and oocyte maturation and ovulation in cattle and pigs. Arch. Tierzucht 44:9-23.

Kim S., Lee G.S., Lee S.H., Kim H.S., Jeong Y.W., Kim J.H., Kang S.K., Lee B.C. \& Hwang W.S. 2005. Embryotropic effect of insulin-like growth factor (IGF)-I and its receptor on development of porcine preimplantation embryos produced by in vitro fertilization and somatic cell nuclear transfer. Mol. Reprod. Dev. 72:88-97.

Knox R.V. 2005. Recruitment and selection of ovarian follicles for determination of ovulation rate in the pig. Dom. Anim. Endocrinol. 29:385-397.

Mao J., Smith M.F., Rucker E.B., Wu G.M., McCauley T.C., Cantley T.C., Prather R.S., Didion B.A. \& Day B.N. 2004. Effect of epidermal growth factor and insulin-like growth factor I on porcine preantral follicular growth, antrum formation, and stimulation of granulosal cell proliferation and suppression of apoptosis in vitro. J. Anim. Sci. 82:1967-1975.

Monget P., Fabre S., Mulsant P., Lecerf F., Elsen J.M., Mazerbourg S., Pisselet C. \& Monniaux D. 2002. Regulation of ovarian folliculogenesis by IGF and BMP system in domestic animals. Dom. Anim. Endocrinol. 23:139-154.

Neira J.A., Tainturier D., Peña M.A. \& Martal J. 2010. Effect of the association of IGF-I, IGF-II, bFGF, TGF-beta1, GM-CSF, and LIF on the development of bovine embryos produced in vitro. Theriogenology 73:595-604.

Oberlender G., Murgas L.D.S., Zangeronimo M.G., Silva A.C., Menezes T.A., Pontelo T.P. \& Vieira L.A. 2013. Role of insulin-like growth factor-I and follicular fluid from ovarian follicles with different diameters on porcine oocyte maturation and fertilization in vitro. Theriogenology 80:319327.

Park C.H., Lee S.G., Choi D.H. \& Lee C.K. 2009. A modified swim-up method reduces polyspermy during in vitro fertilization of porcine oocytes. Anim. Reprod. Sci. 115:169-181.

Pawshe C.H., Rao K.B. \& Totey S.M. 1998. Effect of insulin-like growth factor I and its interaction with gonadotropins on in vitro maturation and embryonic development, cell proliferation, and biosynthetic activity of cumulus-oocyte complexes and granulosa cells in buffalo. Mol. Reprod. Dev. 49:277-285.

Reed M.L., Estrada J.L., Illera M.J. \& Petters R.M. 1993. Effects of epidermal growth factor, insulin-like growth factor-I, and dialyzed porcine follicular fluid on porcine oocyte maturation in vitro. J. Exp. Zool. 266:74-78.

Rhind S.M. \& Schanbacher B.D. 1991. Ovarian follicle populations and ovulation rates of Finnish Landrace cross ewes in different nutritional states and associated profiles of gonadotrophins, inhibin, growth hormone $(\mathrm{GH})$ and insulin-like growth factor-I. Dom. Anim. Endocrinol. 8:281-291.

Samaras S.E., Hagen D.R., Bryan K.A., Mondschein J.S., Canning S.F. \& Hammond J.M. 1994. Effects of growth hormone and gonadotropin on the insulin-like growth factor system in the porcine ovary. Biol. Reprod. 50:178-186.

Santiago C.A., Voge J.L., Aad P.Y., Allen D.T., Stein D.R., Malayer J.R. \& Spicer L.J. 2005. Pregnancy-associated plasma protein-A and insulin-like growth factor binding protein mRNAs in granulosa cells of dominant and subordinate follicles of preovulatory cattle. Dom. Anim. Endocrinol. 28:46-63.

Singhal S., Prasad S., Singh B., Prasad J.K. \& Gupta H.P. 2009. Effect of including growth factors and antioxidants in maturation medium used for in vitro culture of buffalo oocytes recovered in vivo. Anim. Reprod. Sci. 113:44-50.

Spicer L.J. \& Echternkamp S.E. 1995. The ovarian insulin and insulin-like growth factor system with an emphasis on domestic animals. Dom. Anim. Endocrinol. 12:223-245.

Spicer L.J., Santiago C.A., Davidson T.R., Bridges T.S. \& Chamberlain C.S. 2005. Follicular fluid concentrations of free insulin-like growth factor (IGF)-I during follicular development in mares. Dom. Anim. Endocrinol. 29:573-581.

Trout W.E., Killen J.H., Christenson R.K., Schanbacher B.D. \& Ford J.J. 1992. Effects of weaning on concentrations of inhibin in follicular fluid and plasma of sows. J. Reprod. Fert. 94:107-114.

Vatzias G. \& Hagen D.R. 1999. Effects of porcine follicular fluid and oviduct-conditioned media on maturation and fertilization of porcine oocytes in vitro. Biol. Reprod. 60:42-48.

Yoon K.W., Shin T.W., Park J.I., Roh S., Lim J.M., Lee B.C., Hwang W.S. \& Lee E.S. 2000. Development of porcine oocytes from preovulatory follicles of different sizes after maturation in media supplemented with follicular fluids. Reprod. Fertil. Dev. 12:133-139.

Xia P., Tekpetey F.R. \& Armstrong D.T. 1994. Effect of IGF-I on pig oocyte maturation, fertilization, and early embryonic development in vitro, and on granulosa and cumulus cell biosynthetic activity. Mol. Reprod. Dev. 38:373-379.

Zhou H. \& Zhang Y. 2005. Effect of growth factors on in vitro development of caprine preantral follicle oocytes. Anim. Reprod. Sci. 90:265272 . 